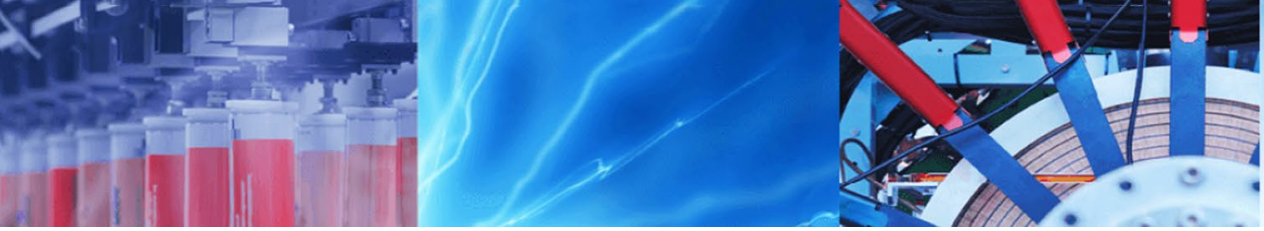

Research Article

\title{
Antibacterial activity and possible mechanisms of one-step synthetic laminated flower-like nickelous(II) hydroxide
}

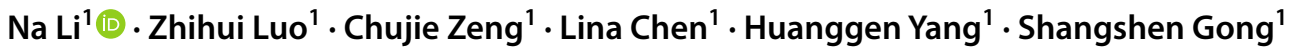

(c) Springer Nature Switzerland AG 2019

\begin{abstract}
It is very urgent to design and fabricate a new generation of bactericidal materials for confronting the increasing prevalence of antibacterial resistance. Here, we propose laminated flower-like nickelous(II) hydroxide as antibacterial agent and explore its possible antibacterial action. The nickelous(II) hydroxide were synthesized by simple one-step hydrothermal process. The antibacterial properties of nickelous(II) hydroxide were tested by bacterial growth curves and colonies growth on agar nutritive plates. The nickelous(II) hydroxide exhibited a strong, stable and long-term antibacterial activity and killed $>95.0 \%$ of both the Gram-negative bacteria Escherichia coli and the Gram-positive bacteria Staphylococcus aureus at $250 \mu \mathrm{g} / \mathrm{mL}$. Antibacterial action was investigated by scanning electron microscopy, transmission electron microscopy, detection of $\mathrm{Ni}^{2+}$ residual, measurement of DNA and RNA release and reactive oxygen species generation analysis. Mechanistically, it killed both Gram-positive and Gram-negative bacteria through physical disruption of the cell membrane structure, causing a loss of cell viability. The antibacterial action would endow nickelous(II) hydroxide with the ability to escape some known mechanisms of antibacterial resistance as a promising long-term bactericide.
\end{abstract}

Keywords Nickelous(II) hydroxide · Antibacterial activity · Mechanisms · Physical disruption · Membrane structure

\section{Introduction}

The disease caused by pathogenic bacterial infections has been affecting human health throughout the world, leading to higher morbidity and mortality [1,2]. The conventional treatments of pathogenic bacteria with antibiotics and antimicrobial agents over years have made many microorganisms resistant to these antimicrobials [3-6]. Microbial drug resistance has caused serious risks in the biomedical field (agriculture and public health) and therefore motivated researchers to concentrate on exploring safe, inexpensive and effective antimicrobial treatment strategies for fighting against bacterial targets [6-8]. However, among the various strategies, the nanomaterials will afford a very promising approach due to their unique structure, physico-chemical properties and good biocompatibility or chemically incorporated antimicrobial activity [9-17]. Recently, some nanomaterials utilized to resist against pathogenic microorganism have made great advances. For example, silver-based nanomaterials such as silver nanoparticles (Ag NPs) and silver complexes have been reported to show high antibacterial activities [18-26]. Carbon-based nanomaterials, such as carbon nanotubes, graphene and its derivatives, also have been widely reported to hold great promise for combating microbial infections [27-33]. In addition, previous researches have demonstrated that metal oxide nanomaterials (such as $\mathrm{TiO}_{2}, \mathrm{ZnO}$ and $\mathrm{MgO}$ ) exhibit antibacterial efficacy [34-39]. The nanomaterials as bacteriostatic agents has recently become a focus of intense research due to their steady and efficient antibacterial activity. Moreover, it is very important to study the antibacterial mechanisms of nanomaterials. A variety of mechanisms for the antibacterial activity of nanomaterials have been

$\triangle \mathrm{Na}$ Li, In19860622@126.com | 'Guangxi Key Laboratory of Agricultural Resources Chemistry and Biotechnology, College of Chemistry and Food Science, Yulin Normal University, 1303 Jiaoyudong Road, Yulin 537000, People's Republic of China.

SN Applied Sciences (2019) 1:931 | https://doi.org/10.1007/s42452-019-0965-7 
proposed, including the reactive oxygen species (ROS) production, mechanical damage to the cell membrane, entrapment, metal ion release and so on $[9,14,32,33]$. However, the exact mechanisms of these nanomaterials as bactericide are not yet fully understood, which could limit the application of nanomaterials in the field of antibacterial agents. Currently, an increase of pernicious antibiotic resistant bacteria is motivating a search for novel, low-cost and effective antibacterial material as well as an exploration for their antibacterial mechanism. Therefore, the generation of materials with more effective antibacterial capabilities is still anticipated.

The goal of this study is to investigate the antibacterial activity and possible antibacterial mechanism of laminated flower-like nickelous(II) hydroxide $\left(\mathrm{Ni}(\mathrm{OH})_{2}\right)$ against microbes. The $\mathrm{Ni}(\mathrm{OH})_{2}$-based materials have been reported to be the most promising electrode material due to its low cost, easy preparation, ultrahigh specific capacitance and environmental friendliness [40-43]. It's easy to synthesize $\mathrm{Ni}(\mathrm{OH})_{2}$ with variant crystalline structures and morphologies as a promising material for multifunctional applications [44-46]. And most striking, the three-dimensional (3D) laminated flower-like $\mathrm{Ni}(\mathrm{OH})_{2}$ particles with a large number of active sites have extraordinary mechanical and electrical properties that show some potential in manufacturing, environmental, and biomedical applications [47-50]. The unique and extensive changeable structure and physicochemical properties have been inspiring us in using it as a biocide in antibacterial treatment. However, recent studies have few reported that $\mathrm{Ni}(\mathrm{OH})_{2}$ materials exhibited significant antibacterial activities to bacteria. Up to date, the mechanism of $\mathrm{Ni}(\mathrm{OH})_{2}$-mediated bacteria killing has not previously been identified. As we all know, that's very important to fully understand the toxicity mechanisms of $\mathrm{Ni}(\mathrm{OH})_{2}$ materials as antimicrobial agents in order to predict their ecotoxicity and environmental impact. A clear antibacterial mechanism of $\mathrm{Ni}(\mathrm{OH})_{2}$ is helpful to explore the application of these materials in food industry, water treatment, biomedical engineering and daily chemical.

In the study, the laminated flower-like $\mathrm{Ni}(\mathrm{OH})_{2}$ had been synthesized through one-step hydrothermal method. The concept of laminated $\mathrm{Ni}(\mathrm{OH})_{2}$ as an efficient $3 \mathrm{D}$ antimicrobial system is illustrated in Scheme 1. The antibacterial activity of $\mathrm{Ni}(\mathrm{OH})_{2}$ against Gram-positive and Gram-negative bacteria were for the first examined and proved to explore its potential as a new and effective antibacterial material for fighting pathogenic microorganism. Moreover, the antibacterial mechanism of $\mathrm{Ni}(\mathrm{OH})_{2}$, had also been examined and proposed. This will open a door for threedimensional materials in the antibacterial applications.

\section{Materials and methods}

\subsection{Materials and reagents}

Carbamide and nickel nitrate were purchased from Sinopharm Chemical Reagent Co., Ltd. (Shanghai, China).2', 7'-dichlorofluorescein diacetate (DCFH-DA) had been purchased from Sigma-Aldrich. LB agar powder and sulfadiazine were purchased from Sinopharm Chemical Reagent Co., Ltd. All chemicals concerned were of analytical grade or the highest purity available. Ultrapure water $(18 \mathrm{M} \Omega \mathrm{cm})$ was used in the experiments. Both Escherichia coli (E. coli) and Staphylococcus aureus (S. aureus) had been provided by the State Key Laboratory of Agricultural Microbiology of Huazhong Agricultural University.

\subsection{Preparation and characterization of $\mathrm{Ni}(\mathrm{OH})_{2}$}

The carbamide of $0.15 \mathrm{~g}$ was added to $20 \mathrm{~mL} 0.025 \mathrm{~mol} / \mathrm{L}$ nickel nitrate solution with stirring at room temperature for $10 \mathrm{~min}$. The solution was transferred to a $100 \mathrm{~mL}$ Teflon-lined stainless steel autoclave. The autoclave was heated at $170{ }^{\circ} \mathrm{C}$ for $12 \mathrm{~h}$ and then cooled naturally along
Scheme 1 Schematic diagram of the laminated $\mathrm{Ni}(\mathrm{OH})_{2}$ as antibacterial platform

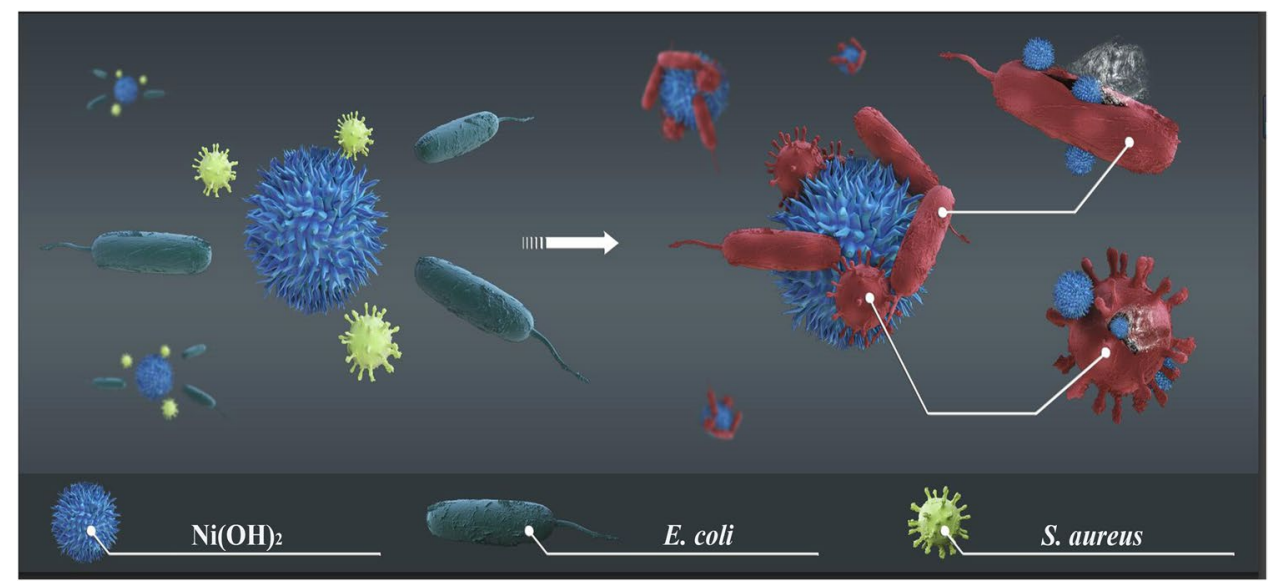


with the substrate. The product was washed with deionized water for 5 times and then dried, yielding $\mathrm{Ni}(\mathrm{OH})_{2}$ powders. The morphology of the products was obtained by a scanning electron microscopy (SEM, Hitachi High Technologies, Japan). X-ray powder diffraction (XRD) analysis was carried out by X-ray powder diffractometer (Rigaku D/max-2500, Japan).

\subsection{Preparation of bacterial solutions}

Gram-negative E. coli and Gram-positive S. aureus respectively grown in LB (Luria-Bertani) broth medium at $37^{\circ} \mathrm{C}$ and shaken for overnight. The bacterial cultures were harvested by centrifuging. Subsequently, the bacteria pellets were washed three times with deionized water. Finally, the cells were resuspended in deionized water and diluted to an optical density of 0.1 at $600 \mathrm{~nm}$ $\left(\mathrm{OD}_{600}=0.1\right)$ for the following analysis.

\subsection{Antibacterial activity experiments}

The antibacterial ability of $\mathrm{Ni}(\mathrm{OH})_{2}$ was determined by the colony count method and the measurement of optical density at $600 \mathrm{~nm}$ at different concentrations within the LB broth medium. A $200 \mu \mathrm{L}$ of bacteria suspension was respectively mixed with and without $20 \mu \mathrm{L}$ of $\mathrm{Ni}(\mathrm{OH})_{2}$ suspension solution with different concentrations and incubated in a shaker at $37^{\circ} \mathrm{C}$ for $3 \mathrm{~h}$. The reaction mixture was then dispersed in $10 \mathrm{~mL} L B$ medium at $37^{\circ} \mathrm{C}$. A serial mixture was spread onto LB agar plates at $37^{\circ} \mathrm{C}$. Then the formation of colonies was determined and compared with control plates to calculate cell viability. For the growth curve test, the optical density at $600 \mathrm{~nm}\left(\mathrm{OD}_{600}\right)$ of all samples would be measured through a Nicolet Evolution 300 ultraviolet visible spectrometer at the preordained time intervals. Bacterial growth curves were created by plotting OD values versus time. All treatments were prepared in triplicate.

Besides, the long-term antibacterial activity of $\mathrm{Ni}(\mathrm{OH})_{2}$ had been investigated. It was tested that the change of antibacterial effectiveness of the $\mathrm{Ni}(\mathrm{OH})_{2}$ after storage in solutions for 1 week, 2 weeks, 3 weeks, 4 weeks, 5 weeks, 6 weeks, 7 weeks and 8 weeks at room temperature. Then, the $\mathrm{Ni}(\mathrm{OH})_{2}$ samples were respectively transferred from the tubes into a bacterial suspension. After incubation for $3 \mathrm{~h}$, the bacterial suspensions were respectively diluted in a gradient and cultured on LB plates to calculate the bactericidal cell mortality (\%). All treatments were also prepared in triplicate.

\subsection{Examination of integrity of cell membranes}

The morphological and ultrastructural changes of bacterial cells were investigated by scanning electron microscope (SEM, JEOL JSM-6700F) and transmission electron microscope (TEM, Hitachi H-7650). After incubated with $\mathrm{Ni}(\mathrm{OH})_{2}$, the bacteria were collected and quickly fixed with $2 \%$ glutaraldehyde and $1 \%$ osmium tetroxide. Then the cells were dehydrated with ethanol for $20 \mathrm{~min}$. The dried samples were sputter coated with gold for SEM analysis. For TEM, the collected bacteria were pelleted and fixed overnight with a $4 \%$ formaldehyde and $1 \%$ glutaraldehyde fixative. Following washed with buffer solution, the samples were postfixed with $1 \%$ osmium tetroxide for $1 \mathrm{~h}$, dehydrated in graded concentrations of ethanol, and embedded in epoxy resin. The sections were cut using a Leica EM UC6 ultramicrotome and were examined for TEM.

To further verify the integrity of cell membranes, the ultraviolet-visible spectroscopy at $260 \mathrm{~nm}$ was examined. If the bacteria membrane is disrupted, the amount of DNA and RNA released from the cytoplasm can be estimated by the detection of absorbance at $260 \mathrm{~nm}$. Both bacteria cells were respectively incubated with $\mathrm{Ni}(\mathrm{OH})_{2}$ solutions under different shaking speed. The bacterial suspensions were then immediately filtered with $0.22 \mu \mathrm{m}$ syringe filters to remove the bacteria. The optical density at $260 \mathrm{~nm}$ was recorded. Besides, after incubated with $\mathrm{Ni}(\mathrm{OH})_{2}$ under different shaking speed, the bacteria cells were transferred to LB agar plates and the cell death rate (\%) was measured.

\subsection{Impact of bacteriostatic agent}

Sulfadiazine was dissolved in a mixture of methanol and acetone at $10 \mathrm{mg} / \mathrm{mL}$. A $10 \mu \mathrm{L}$ sulfadiazine was added into the mixture of bacterial suspensions and $\mathrm{Ni}(\mathrm{OH})_{2}$ dispersion $(100 \mu \mathrm{g} / \mathrm{mL})$. The bacterial suspensions were then incubated for $3 \mathrm{~h}$ at $37^{\circ} \mathrm{C}$. In control experiments, $10 \mu \mathrm{L}$ sulfadiazine was added into bacterial suspensions without $\mathrm{Ni}(\mathrm{OH})_{2}$. The cell death rates (\%) were measured by the colony forming count method.

\subsection{Detection of $\mathrm{Ni}^{2+}$}

The amount of nickel residues left in the $\mathrm{Ni}(\mathrm{OH})_{2}$ dispersions was determined by inductively coupled plasma mass spectrometry (ICP-MS) analysis. The antibacterial activity of $\mathrm{Ni}^{2+}$ was studied using the colony forming count method. Thereupon, the nickel nitrate solution of different concentrations was inoculated with $1 \mathrm{~mL}$ of the bacteria suspension of $E$. coli and S. aureus, respectively, at $37^{\circ} \mathrm{C}$ for $3 \mathrm{~h}$ with gentle shaking. Then, the reaction mixture was respectively spread onto $L B$ agar plates at $37^{\circ} \mathrm{C}$ and the formation of colonies was determined. 


\subsection{Reactive oxygen species (ROS) generation analysis}

To measure whether the antibacterial process is dependent upon reactive oxygen species (ROS), DCFH-DA was applied to test the level of bacterial ROS induced by $\mathrm{Ni}(\mathrm{OH})_{2}$. E. coli and S. aureus cells were respectively inoculated with $10 \mu \mathrm{M}$ of DCFH-DA at $37^{\circ} \mathrm{C}$ for $30 \mathrm{~min}$. Then, the cells were respectively treated with and without the $50,100,200 \mu \mathrm{g} / \mathrm{mL}$ of $\mathrm{Ni}(\mathrm{OH})_{2}$ for $3.0 \mathrm{~h}$. The fluorescence intensity was detected at excitation/emission wavelength of $488 / 525 \mathrm{~nm}$.

\section{Results and discussion}

\subsection{Synthesis and characterization of $\mathrm{Ni}(\mathrm{OH})_{2}$}

The laminated flower-like $\mathrm{Ni}(\mathrm{OH})_{2}$ was prepared by hydrothermal method. Figure 3 E shows $\mathrm{SEM}$ images of $\mathrm{Ni}(\mathrm{OH})_{2}$. Irregular morphology and size can be observed in the SEM image. The SEM revealed well laminated flower-like structure. The stacked lamellas were expected to provide a high surface area for contacting bacteria and improving antimicrobial performance. Additionally, a typical XRD pattern of the dried $\mathrm{Ni}(\mathrm{OH})_{2}$ is shown in Fig. $1 \mathrm{~B}$. The $\mathrm{Ni}(\mathrm{OH})_{2}$ showed the sharp characteristic peaks at $12.1^{\circ}, 19.7^{\circ}, 25.7^{\circ}, 40.2^{\circ}$ and $60.7^{\circ}$, which could be attributed to the (001), (100), (003), (014) and (110) planes of $\mathrm{Ni}(\mathrm{OH})_{2}$.

\subsection{Antibacterial activity of $\mathrm{Ni}(\mathrm{OH})_{2}$}

The bactericidal activity of $\mathrm{Ni}(\mathrm{OH})_{2}$ was tested with E. coli and $\mathrm{S}$. aureus by the measurement of surviving cells under the treatment of $\mathrm{Ni}(\mathrm{OH})_{2}$ through the colony counting method. Figure 2 shows the typical photographs of E. coli and S. aureus bacteria colonies after treated with various concentrations of $\mathrm{Ni}(\mathrm{OH})_{2}$. Both bacterias grown well in the absence of $\mathrm{Ni}(\mathrm{OH})_{2}$, whereas a marked decrease in bacterial survival occured after exposed to the $\mathrm{Ni}(\mathrm{OH})_{2}$. As the concentration of $\mathrm{Ni}(\mathrm{OH})_{2}$ increased to $250 \mu \mathrm{g} / \mathrm{mL}$, the cells were almost completely killed. Figure $3 \mathrm{~A}, \mathrm{~B}$ show the bacterial viability can decrease with increasing concentration of $\mathrm{Ni}(\mathrm{OH})_{2}$. The bacterial viability was both decreased to less than $5 \%$ at $250 \mu \mathrm{g} / \mathrm{mL}$ of $\mathrm{Ni}(\mathrm{OH})_{2}$. Thus, the $\mathrm{Ni}(\mathrm{OH})_{2}$ materials had strong antimicrobial activity against $E$. coli and S. aureus and the bactericidal activity increased with increasing $\mathrm{Ni}(\mathrm{OH})_{2}$ concentration.

To further see if the $\mathrm{Ni}(\mathrm{OH})_{2}$ besides showing bactericidal properties also can cause growth inhibition in the nutrient solution, the optical density at $600 \mathrm{~nm}$ $\left(\mathrm{OD}_{600}\right)$ was measured to monitor bacterial growth. The ODs shown in Fig. 3C, D demonstrate that the growth inhibition effect of $\mathrm{Ni}(\mathrm{OH})_{2}$ became more significant as the concentration of $\mathrm{Ni}(\mathrm{OH})_{2}$ increased, whereas $250 \mu \mathrm{g} /$ $\mathrm{mL} \mathrm{Ni}(\mathrm{OH})_{2}$ showed a significant growth inhibition effect against $E$. coli and S. aureus. The antibacterial effect in a concentration-dependent manner shown that a higher concentration of $\mathrm{Ni}(\mathrm{OH})_{2}$ would result in superior inhibitory effect on the both bacterias. Thus, a new type of antimicrobial material showed much potential in antimicrobial systems. Overall, the antimicrobial activity datas indicated that the $\mathrm{Ni}(\mathrm{OH})_{2}$ possessed very high antibacterial activities against Gram-negative and Gram-positive bacterias. In addition, the long-term antibacterial activity of $\mathrm{Ni}(\mathrm{OH})_{2}$ had been investigated. It was tested that the change of antibacterial effectiveness of the $\mathrm{Ni}(\mathrm{OH})_{2}$ after storage in solutions for different time. In the Fig. $3 \mathrm{E}$ and $F$, the bacterial cell mortality shows no significant changes with storage time. The cell mortality of both $E$. coli and S. aureuswas still very high after 8 weeks of storage. These results demonstrated that the $\mathrm{Ni}(\mathrm{OH})_{2}$ could act as a kind of long-term effective antibacterial agent.
Fig. 1 A SEM image and B XRD patterns of $\mathrm{Ni}(\mathrm{OH})_{2}$
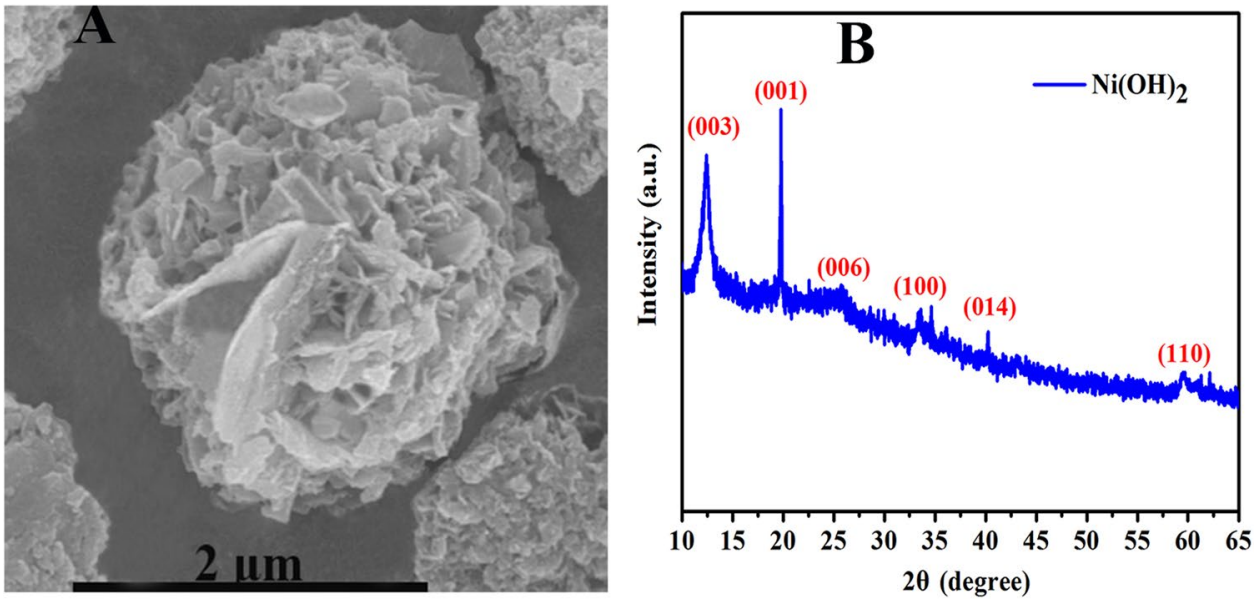

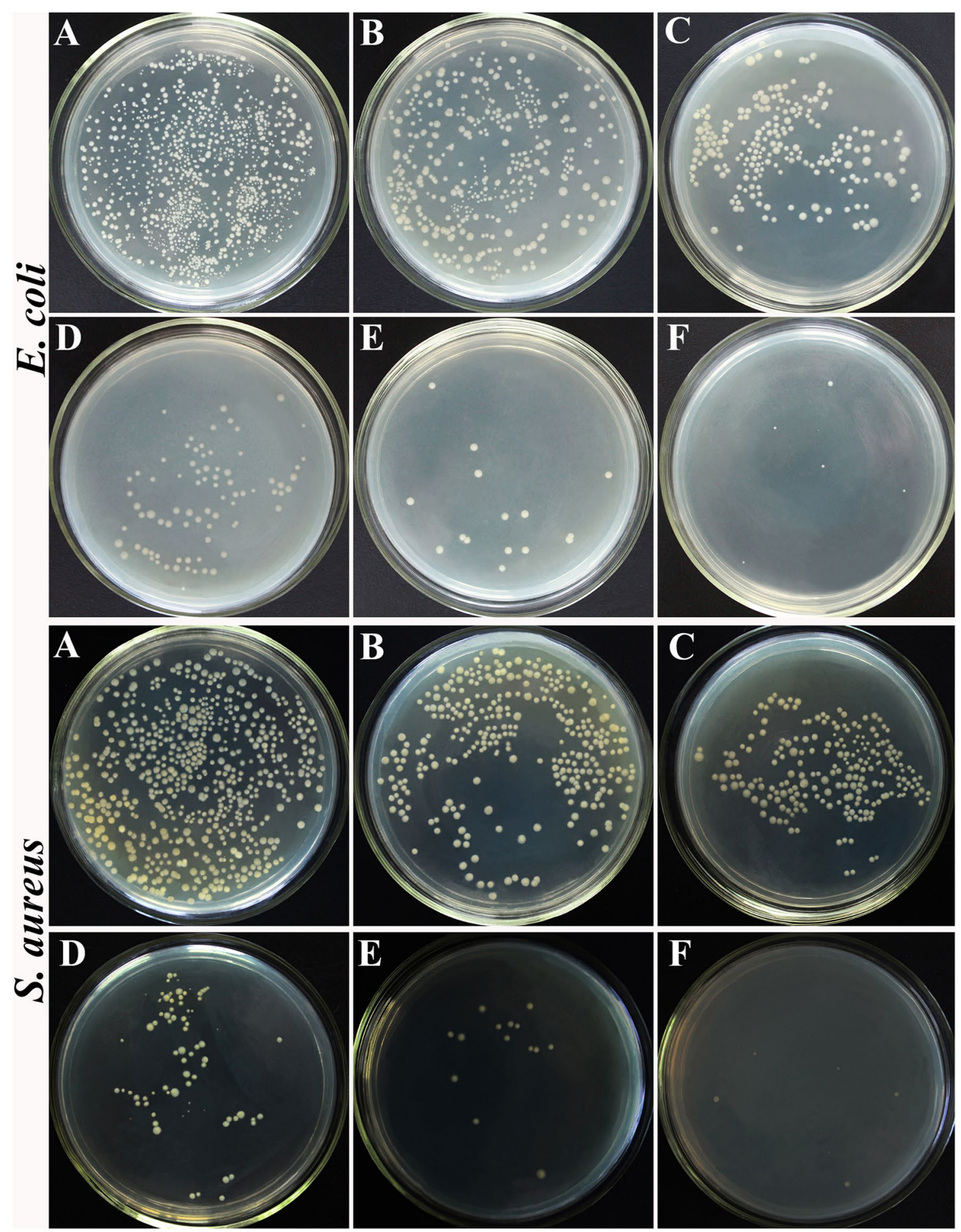

Fig. 2 Concentration dependent antibacterial activities of the $\mathrm{Ni}(\mathrm{OH})_{2}$ : photographs of agar plates onto which $E$. coli (top panel) and S. aureus (bottom panel) bacterial cells were recultivated after treatment for $3 \mathrm{~h}$ with $0 \mu \mathrm{g} / \mathrm{mL}$ (A), $50 \mu \mathrm{g} / \mathrm{mL}$ (B), $100 \mu \mathrm{g} / \mathrm{mL}$ (C), $150 \mu \mathrm{g} / \mathrm{mL}$ (D), $200 \mu \mathrm{g} / \mathrm{mL}$ (E), and $250 \mu \mathrm{g} / \mathrm{mL}$ (F) 

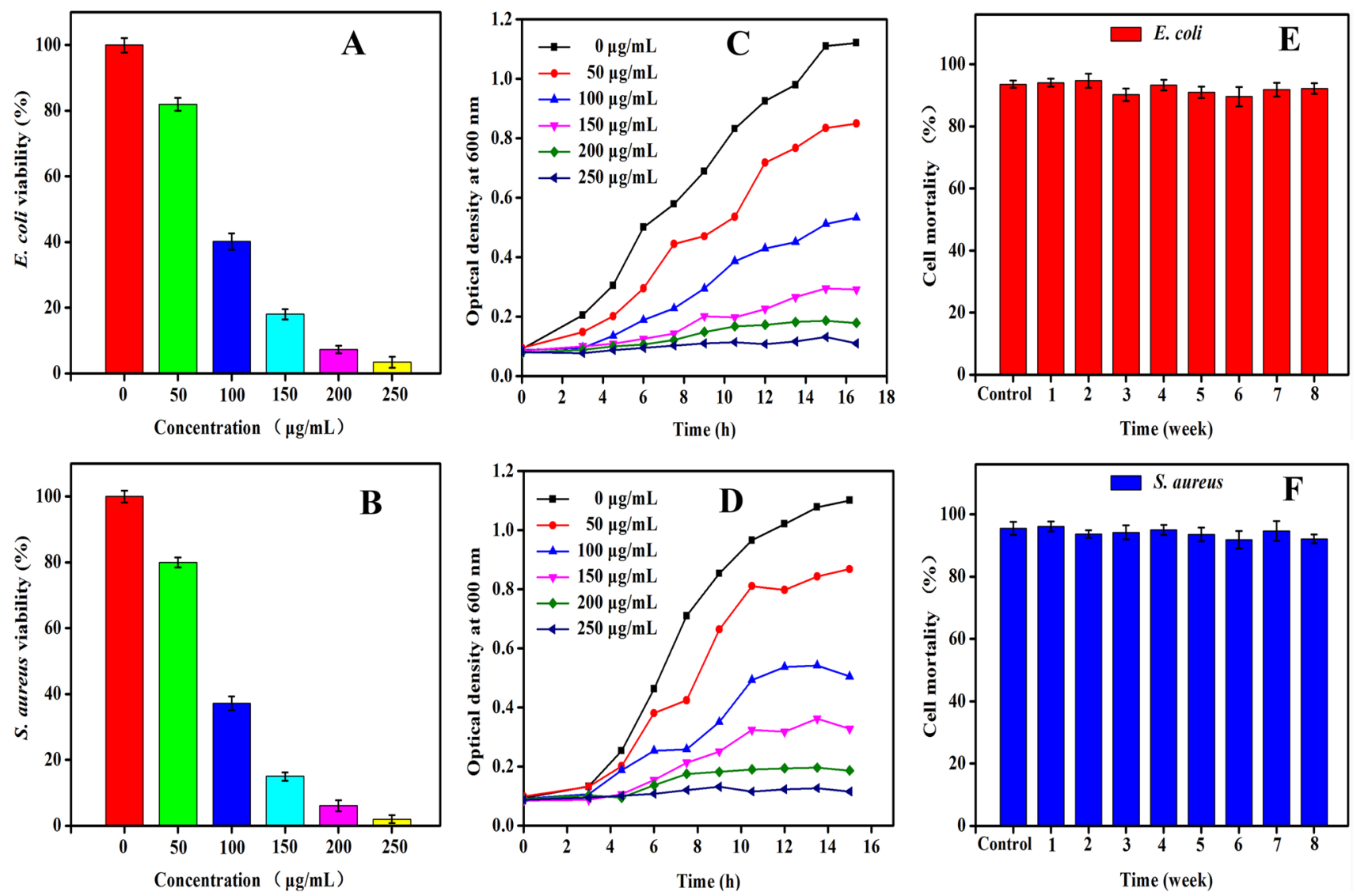

Fig. 3 Cell viability measurements of A E. coli and B S. aureus treated with $\mathrm{Ni}(\mathrm{OH})_{2}$. OD regrowth curves of C E. coli and D S. aureus treated with $\mathrm{Ni}(\mathrm{OH})_{2}$. Long-term antibacterial effectiveness of $\mathbf{E}$ E. coli and $\mathbf{F}$ S. aureus treated with $\mathrm{Ni}(\mathrm{OH})_{2}$

\subsection{Antibacterial mechanism of $\mathrm{Ni}(\mathrm{OH})_{2}$}

\subsubsection{Destruction of bacterial membrane}

To investigate the changes of bacterial morphology caused by the antibacterial system, SEM was employed to observe E. coli and S. aureus before and after $\mathrm{Ni}(\mathrm{OH})_{2}$ treatment. As can be seen in Fig. 4A, B, as control groups, E. coli and S. aureus cells were respectively rod-shaped and spherical-shaped with smooth and intact cell walls. In contrast, after treated with $\mathrm{Ni}(\mathrm{OH})_{2}$ (Fig. $4 \mathrm{C}, \mathrm{D}$ ), both bacterias were trapped by the $\mathrm{Ni}(\mathrm{OH})_{2}$ and formed agglomerates, indicating the $\mathrm{Ni}(\mathrm{OH})_{2}$ can interact with the cells. To further explore the antibacterial behavior, TEM was used to investigate the intracellular structural changes of E. coli and S. aureus. As shown in Fig. 4E, F, E. coli is rod-shaped with smooth surface and $S$. aureus is spherical-shaped with smooth surface. After treatment with $\mathrm{Ni}(\mathrm{OH})_{2}$ materials, as shown in Fig. $4 \mathrm{G}, \mathrm{H}$, the irreversible damages can be induced on both bacterial cells. It was observed that the holes in bacterial cells occurred and significant intracellular substrate leaked since the $\mathrm{Ni}(\mathrm{OH})_{2}$ could attack cells in the solution.

The physical punctures of bacterial membrane were further illustrated by changing the shaking speed during incubation and then monitoring the release of cytoplasmaic constituents (such as DNA and RNA) $[9,51]$. The optical density (OD) ratio of a bacterium suspension with $\mathrm{Ni}(\mathrm{OH})_{2}$ to a bacterium suspension without $\mathrm{Ni}(\mathrm{OH})_{2}$ is plotted in Fig. 5A, B. A remarkable increment by a factor of 6.8 and 7.4 times after $E$. coli and $S$. aureus respectively interacting with $\mathrm{Ni}(\mathrm{OH})_{2}$ at $200 \mathrm{rpm}$ is observed, indicating that more mobile will enhance their physical punctures on bacteria. In Fig. 5C, D, the death rates of both $E$. coli and $S$. aureus increase with the increase of shaking speeds, indicating a higher shaking speed can remarkably enhance the mobility of both bacterias. Thus, the lamella on $\mathrm{Ni}(\mathrm{OH})_{2}$ may act as a sharp blade to pierce into the cell membranes through directly contacting with the bacteria. More punctures of $\mathrm{Ni}(\mathrm{OH})_{2}$ on bacterial membranes can result in more severe destruction of bacterial membranes, ultimately increasing cell death rates. 
Fig. 4 SEM images of A E. coli and $\mathbf{B} S$. aureus treated without $\mathrm{Ni}(\mathrm{OH})_{2}$, and C E. coli and D S. aureus treated with $\mathrm{Ni}(\mathrm{OH})_{2}$. TEM images of $\mathbf{E} E$. coli and $\mathbf{F} S$. aureus treated without $\mathrm{Ni}(\mathrm{OH})_{2}$ and $\mathbf{G}$ E. coli and $\mathbf{H}$ S. aureus treated with $\mathrm{Ni}(\mathrm{OH})_{2}$
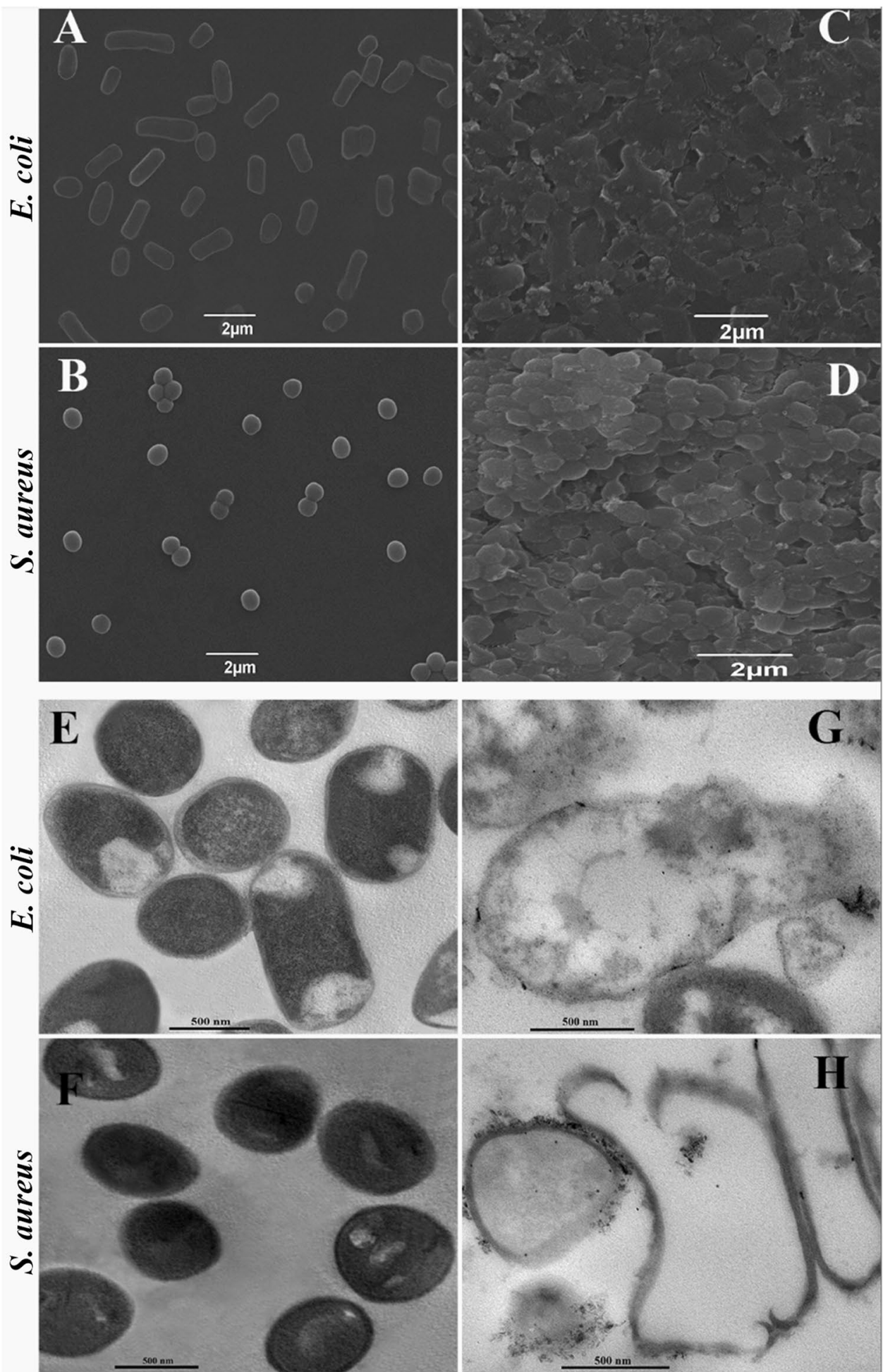

However, except that the physical destruction can induce antimicrobial activities, other factors may also affect the antimicrobial activities, such as inhibiting cell growth. To verify whether the bacterial death may be induced by inhibiting the cell growth, thus the impact of sulfadiazine as a bacteriostatic agent on the cells was investigated $[9,52]$. The growth and reproduction of bacteria can be inhibited by the sulfadiazine without killing bacteria. The death rates of both bacterias after incubated with different samples were compared. As shown in Fig. $6 \mathrm{~A}$, the both bacterias incubated only with sulfadiazine have a less than $10 \%$ death rate, but 
Fig. 5 Releasing of $260 \mathrm{~nm}$ absorbing materials from $\mathbf{A} E$. coli and B S. aureus after incubating with $\mathrm{Ni}(\mathrm{OH})_{2}$ at different shaking speeds. Death rate of C E. coli and D S. aureus after incubating with $\mathrm{Ni}(\mathrm{OH})_{2}$ at different shaking speeds
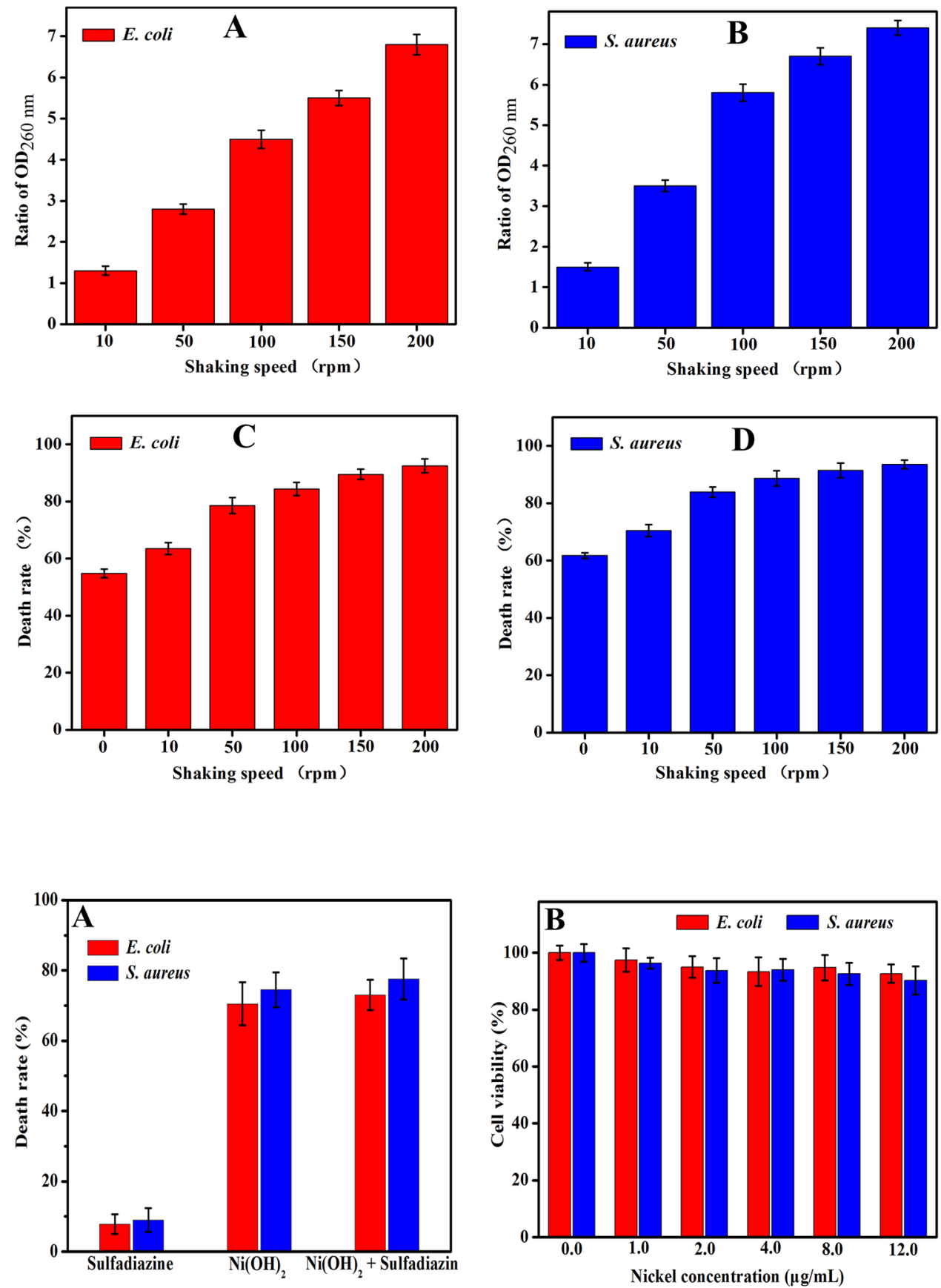

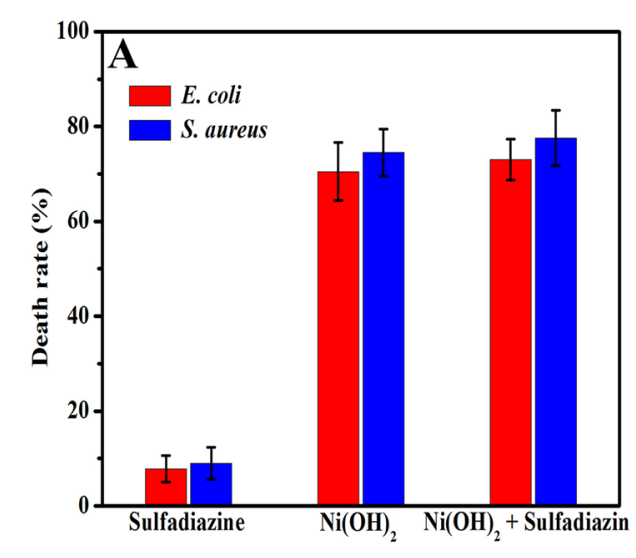

Fig. 6 A Cell viability measurements of $E$. coli and S. aureus treated with different solutions. B Antibacterial activities of nickel(II) at different concentration the death rates of both bacterias after incubated with $\mathrm{Ni}(\mathrm{OH})_{2}$ and sulfadiazine are almost the same high as incubating the bacterias using $\mathrm{Ni}(\mathrm{OH})_{2}$ alone. These results illuminated that the inhibiting cell growth by $\mathrm{Ni}(\mathrm{OH})_{2}$ was not a major cause responsible for the death of cells in this study. Therefore, the physical membrane disruption might be a major mechanism of cell death. This distinct bactericidal mechanism made $\mathrm{Ni}(\mathrm{OH})_{2}$ promising antibacterial agents to effectively kill bacterias and avoid resistance.

\subsubsection{Influence of nickel residues}

Nickel residues may affect antimicrobial activity $[9,53]$. To measure whether the nickel residues on $\mathrm{Ni}(\mathrm{OH})_{2}$ samples could improve the antibacterial activity, the content of $\mathrm{Ni}^{2+}$ in solutions was analyzed through ICP-MS. The amount of the $\mathrm{Ni}^{2+}$ in solutions was lower than $2.0 \mu \mathrm{g} / \mathrm{mL}$. The potential of the $\mathrm{Ni}^{2+}$ as antibacterial agents was evaluated. Five different samples of $\mathrm{Ni}\left(\mathrm{NO}_{3}\right)_{2}$ solutions were tested to study the antibacterial activities against $E$. coli 
Fig. 7 The level of ROS of $\mathbf{A}$ E. coli and B S. aureus treated $\mathrm{Ni}(\mathrm{OH})_{2}$ at different concentrations
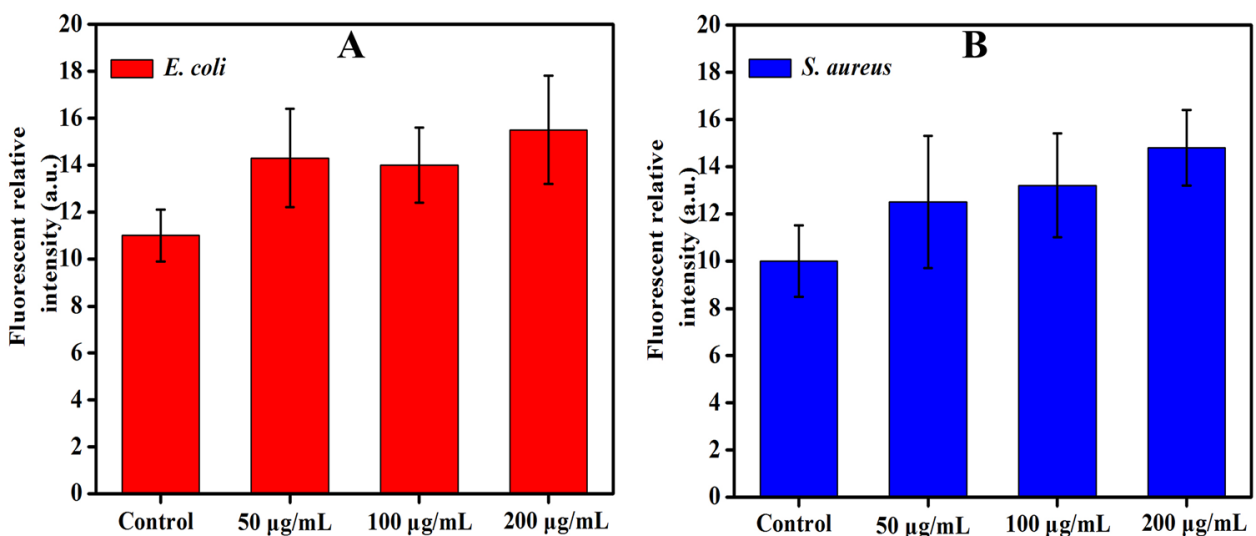

and S. aureus, and the results are shown in Fig. 6B. It can be observed that the bacterial viability did not show significant decrease in the range between 0.0 and $12.0 \mu \mathrm{g} / \mathrm{mL}$, even if the concentration was more than six times higher than the Ni residue left in $\mathrm{Ni}(\mathrm{OH})_{2}$ dispersions. Therefore, the nickel residues can't display impact on the $\mathrm{Ni}(\mathrm{OH})_{2}$ antibacterial activity in this study.

\subsubsection{ROS mediated by $\mathrm{Ni}(\mathrm{OH})_{2}$}

Another possible antibacterial mechanism for $\mathrm{Ni}(\mathrm{OH})_{2}$ is the oxidative stress. To investigate whether $\mathrm{Ni}(\mathrm{OH})_{2}$ exerted ROS-independent oxidative stress on bacteria, the generation of $\mathrm{ROS}$ at different $\mathrm{Ni}(\mathrm{OH})_{2}$ concentrations was monitored using DCFH-DA as the fluorescent probe [54]. As shown in the Fig. 7, no noticeable increase of fluorescence intensity are observed with the increase of $\mathrm{Ni}(\mathrm{OH})_{2}$ concentrations, indicating that the $\mathrm{Ni}(\mathrm{OH})_{2}$ mediated no or negligible ROS production compared with that of the control group. The results proved that the ROS-independent oxidative stress toward bacterial cells was not very related to the antibacterial activity, which had actually played a minimal role in the antibacterial mechanism of $\mathrm{Ni}(\mathrm{OH})_{2}$.

\section{Conclusions}

In summary, the studies demonstrated that the prepared $\mathrm{Ni}(\mathrm{OH})_{2}$ solution can stimulate antibacterial activity against Gram-negative E. coli and Gram-positive S. aureus bacteria in a concentration-dependent manner. From the above results, the potential antibacterial mechanism of $\mathrm{Ni}(\mathrm{OH})_{2}$ were proposed that the delaminated $\mathrm{Ni}(\mathrm{OH})_{2}$ with sharp edges contacted with the surface of microorganisms and the microorganisms were then trapped by the $\mathrm{Ni}(\mathrm{OH})_{2}$; subsequently the $\mathrm{Ni}(\mathrm{OH})_{2}$ pierced cell membrane, leading to the death of the microorganism. It is expected to apply the $\mathrm{Ni}(\mathrm{OH})_{2}$, as an antibacterial agent in medical and biological fields against resistant bacteria and promote extensive studies on other 3D materials as antibacterial agents.

Acknowledgements This work was supported by the National Natural Science Foundation of China (21765022), the Natural Science Foundation of Guangxi Province (2017GXNSFBA198105), the high-level personnel Research Funds of Yulin Normal University (G2017011), the research fund project of Yulin Normal University (2016YJKY08) and the National Natural Science Foundation of China (21767029, 21565028).

\section{Compliance with ethical standards}

Conflict of interest On behalf of all authors, the corresponding author states that there is no conflict of interest.

\section{References}

1. Hetrick EM, Shin JH, Stasko NA, Johnson CB, Wespe DA, Holmuhamedov E, Schoenfisch MH (2008) Bactericidal efficacy of nitric oxide-releasing silica nanoparticles. ACS Nano 2:235-246

2. Gabriel GJ, Som A, Madkour AE, Eren T, Tew GN (2007) Infectious disease: connecting innate immunity to biocidal polymers. Mater Sci Eng R 57:28-64

3. Wyszogrodzka G, Marszałek B, Gil B, Dorożyński P (2016) Metalorganic frameworks: mechanisms of antibacterial action and potential applications. Drug Discov Today 21:1009-1018

4. Sorace L, Benelli C, Gatteschi D (2011) Lanthanides in molecular magnetism: old tools in a new field. Chem Soc Rev 40:3092-3104

5. Kitagawa S, Matsuda R (2007) Chemistry of coordination space of porous coordination polymers. Coord Chem Rev 251:2490-2509

6. Andersson DI, Hughes D (2010) Antibiotic resistance and its cost: is it possible to reverse resistance? Nat Rev Microbiol 8:260-271

7. Wu MC, Deokar AR, Liao JH, Shih PY, Ling YC (2013) Graphenebased photothermal agent for rapid and effective killing of bacteria. ACS Nano 7:1281-1290

8. Natan M, Gutman O, Lavi R, Margel S, Banin F (2015) Killing mechanism of stable N-halamine cross-linked polymethacrylamide nanoparticles that selectively target bacteria. ACS Nano 9:1175-1188

9. Liu S, Wei L, Hao L, Fang N, Chang MW, Xu R, Yang Y, Chen Y (2009) Sharper and faster "nano darts" kill more bacteria: a 
study of antibacterial activity of individually dispersed pristine single-walled carbon nanotube. ACS Nano 3:3891-3902

10. Chen J, Wang F, Liu Q, Du J (2014) Antibacterial polymeric nanostructures for biomedical applications. Chem Commun 50:14482-14493

11. Mahmoudi M, Serpooshan V (2012) Silver-coated engineered magnetic nanoparticles are promising for the success in the fight against antibacterial resistance threat. ACS Nano 6:2656-2664

12. Miller KP, Wang L, Benicewicz BC, Decho AW (2015) Inorganic nanoparticles engineered to attack bacteria. Chem Soc Rev 44:7787-7807

13. Jakobsen V, Viganor L, Blanco-Fernández A, Howe O, DevereuxM McKenzie CJ, McKee V (2018) Tetrameric and polymeric silver complexes of the omeprazole scaffold; synthesis, structure, in vitro and in vivo antimicrobial activities and DNA interaction. J Inorg Biochem 186:317-328

14. Li X, Robinson SM, Gupta A, Saha K, Jiang Z, Moyano DF, SaharA Riley MA, Rotello VM (2014) Functional gold nanoparticles as potent antimicrobial agents against multi-drugresistant bacteria. ACS Nano 8:10682-10686

15. Zhao YY, Ye CJ, Liu WW, Chen R, Jiang XY (2014) Tuning the composition of AuPt bimetallic nanoparticles for antibacterial application. Angew Chem Int Ed 53:8127-8131

16. Zhou Y, Jiang X, Tang J, Su Y, Peng F, Lu Y, Peng R, He Y (2014) A silicon-based antibacterial material featuring robust and high antibacterial activity. J Mater Chem B 2:691-697

17. Yang $X$, Li J, Liang T, Ma C, Zhang Y, Chen H, Hanagata N, Su H, Xu M (2014) Antibacterial activity of two-dimensional MoS, sheets. Nanoscale 6:10126-10133

18. Tian J, Wong KKY, Ho CM, Lok CN, Yu WY, Che CM, Chiu JF, Tam PKH (2007) Topical delivery of silver nanoparticles promotes wound healing. Chem Med Chem 2:129-136

19. Chernousova S, Epple M (2013) Silver as antibacterial agent: ion, nanoparticle, and metal. Angew Chem Int Ed 52:1636-1653

20. Rendošová $M$, VargováZ Sabolová $D$, Imrichová $N$, Hudecová $D$, Gyepes R, Lakatoš B, Elefantová K (2018) Silver pyridine-2-sulfonate complex-its characterization, DNA binding, topoisomerase I inhibition, antimicrobial and anticancer response. J Inorg Biochem 186:206-216

21. Lu Z, Zhang X, Li Z, Wu Z, Song J, Li C (2015) Composite copolymer hybrid silver nanoparticles: preparation and characterization of antibacterial activity and cytotoxicity. Polym Chem 6:772-779

22. Xue P, Shan Y, Shen Q, Li Y, Jiang J, Liu Y, Liu X (2019) Potential impact of organic ligands on the antibacterial activity of silver nanoparticles. New J Chem 43:2870-2874

23. Jin JC, Wu XJ, Xu J, Wang BB, Jiang FL, Liu Y (2017) Ultrasmall silver nanoclusters: highly efficient antibacterial activity and their mechanisms. Biomater Sci 5:247-257

24. Zheng K, Setyawati MI, Lim TP, Leong DT, Xie J (2016) Antimicrobial cluster bombs: silver nanoclusters packed with daptomycin. ACS Nano 10:7934-7942

25. Jin C, Liu X, Tan L, Cui Z, Yang X, Zheng Y, Yeung KWK, Chu PK, Wu S (2018) Ag/AgBr-loaded mesoporous silica for rapid sterilization and promotion of wound healing. Biomater Sci 6:1735-1744

26. Wang Y, Wan J, Miron RJ, Zhao Y, Zhang Y (2016) Antibacterial properties and mechanisms of gold-silver nanocages. Nanoscale 8:11143-11152

27. Anand A, Unnikrishnan B, Wei SC, Chou CP, Zhang LZ, Huang CC (2019) Graphene oxide and carbon dots as broad-spectrum antimicrobial agents. Nanoscale Horiz 4:117-137

28. Seo Y, Hwang J, Lee E, Kim YJ, Lee K, Park C, Choi Y, Jeon H, Choi $J$ (2018) Engineering copper nanoparticles synthesized on the surface of carbon nanotubes for anti-microbial and anti-biofilm applications. Nanoscale 10:15529-15544

29. Ji H, Sun H, Qu X (2016) Antibacterial applications of graphenebased nanomaterials: recent achievements and challenges. Adv Drug Deliv Rev 105:176-189

30. Li Y, Yang D, Cui J (2017) Graphene oxide loaded with copper oxide nanoparticles as an antibacterial agent against Pseudomonas syringae pv. tomato. RSC Adv 7:38853-38860

31. He T, Liu H, Zhou Y, Yang J, Cheng X, Shi H (2014) Antibacterial effect and proteomic analysis of graphene-based silver nanoparticles on a pathogenic bacterium Pseudomonas aeruginosa. Biometals 27:673-682

32. Liu S, Zeng TH, Hofmann M, Burcombe E, Wei J, Jiang R, Kong J, Chen Y (2011) Antibacterial activity of graphite, graphite oxide, graphene oxide, and reduced graphene oxide: membrane and oxidative stress. ACS Nano 5:6971-6980

33. Pham VTH, Truong VK, Quinn MDJ, Notley SM, Guo Y, Baulin VA Kobaisi MA, Crawford RJ, Ivanova EP (2015) Graphene induces formation of pores that kill spherical and rod-shaped bacteria. ACS Nano 9:8458-8467

34. Lemire JA, Harrison JJ, Turner RJ (2013) Antimicrobial activity of metals: mechanisms, molecular targets and applications. Nat Rev Microbiol 11:371-384

35. Applerot G, Lipovsky A, Dror R, Perkas N, Nitzan Y, Lubart R, Gedanken A (2009) Enhanced antibacterial activity of nanocrystalline $\mathrm{ZnO}$ de to increased ROS-mediated cell injury. Adv Funct Mater 19:842-852

36. Cheng $Y$, Yang $H$, Yang $Y$, Huang J, Wu K, Chen $Z$, Wang $X$, Lin $C$, Lai $Y$ (2018) Progress in $\mathrm{TiO}_{2}$ nanotube coatings for biomedical applications: a review. J Mater Chem B 6:1862-1886

37. Akhavan O, Azimirad R, Safa S, Hasani E (2011) $\mathrm{CuO} / \mathrm{Cu}(\mathrm{OH})_{2}$ hierarchical nanostructures as bactericidal photocatalysts. $J$ Mater Chem 21:9634-9640

38. Liu W, Su P, Chen S, Wang N, Ma Y, Liu Y, Wang J, Zhang Z, Li H, Webster TJ (2014) Synthesis of $\mathrm{TiO}_{2}$ nanotubes with $\mathrm{ZnO}$ nanoparticles to achieve antibacterial properties and stem cell compatibility. Nanoscale 6:9050-906239

39. Long M, Zhang Y, Shu Z, Tang A, Ouyang J, Yang H (2017) $\mathrm{Fe}_{2} \mathrm{O}_{3}$ nanoparticles anchored on 2D kaolinite with enhanced antibacterial activity. Chem Commun 53:6255

40. Zhu L, Zhang H, Hu W, Zheng J, Zhang N, Yu C, Ye H, Yang Z, Chen BH (2018) Nickel hydroxide-cobalt hydroxide nanoparticle supported ruthenium-nickel-cobalt islands as an efficient nanocatalyst for the hydrogenation reaction. Chem Cat Chem 10:1998-2002

41. Huang HL, Guo YJ, Cheng YH (2018) Ultrastable a phase nickel hydroxide as energy storage materials for alkaline secondary batteries. Appl Surf Sci 435:635-640

42. Zhao B, Zhang L, Zhang $Q$, Chen $D$, Cheng $Y$, Deng $X$, Chen $Y$, Murphy $R$, Xiong $X$, Song B, Wong CP, Wang MS, Liu M (2018) Rational design of nickel hydroxide-based nanocrystals on graphene for ultrafast energy storage. Adv Energy Mater 8:1702247

43. Shi P, Chen R, Li L, An J, Hua L, Zhou J, Liu B, Chen P, Huang W, Sun $G$ (2013) Holey nickel hydroxide nanosheets for wearable solid-state fiber-supercapacitors. Nanoscale 10:5442-5448

44. Wei W, Wu J, Cui S, Zhao Y, Chen W, Mi L (2019) a-Ni(OH) ${ }_{2} / \mathrm{NiS}_{1.97}$ heterojunction composites with excellent ion and electron transport properties for advanced supercapacitors. Nanoscale 11:6243-6253

45. Wei W, Chen W, Ding L, Cui S, Mi L (2017) Construction of hierarchical three-dimensional interspersed flower-like nickel hydroxide for asymmetric supercapacitors. Nano Res 10:3726-3742

46. Wei W, Cui S, Ding L, Mi L, Chen W, Hu X (2017) Urchin-like $\mathrm{Ni}_{1 / 3} \mathrm{Co}_{2 / 3}\left(\mathrm{CO}_{3}\right)_{1 / 2}(\mathrm{OH}) \cdot 0.11 \mathrm{H}_{2} \mathrm{O}$ for ultrahigh-rate electrochemical supercapacitors: structural evolution from solid to hollow. ACS Appl Mater Interfaces 9:40655-40670 
47. Choi BG, Yang MH, Jung SC, Lee KG, Kim JG, Park H, Park TJ, Lee SB, Han YK, Huh YS (2013) Enhanced pseudocapacitance of ionic liquid/cobalt hydroxide nanohybrids. ACS Nano 7:2453-2460

48. Ji Z, Li N, Zhang Y, Xie M, Shen X, Chen L, Xu K, Zhu G (2019) Nitrogen-doped carbon dots decorated ultrathin nickel hydroxide nanosheets for high-performance hybrid supercapacitor. J Colloid Interface Sci 542:392-399

49. Kim SI, Thiyagarajan P, Jang JH (2014) Great improvement in pseudocapacitor properties of nickel hydroxide via simple gold deposition. Nanoscale 6:11646-11652

50. Lee G, Varanasi CV, Liu J (2015) Effects of morphology and chemical doping on electrochemical properties of metal hydroxides in pseudocapacitors. Nanoscale 7:3181-3188

51. Chen CZS, Cooper SL (2002) Interactions between dendrimer biocides and bacterial membranes. Biomaterials 23:3359-3368
52. Strauss E, Dingle JH, Finland M (1941) Studies on the mechanism of sulfonamide bacteriostasis, inhibition and resistance. J Immunol 42:313-329

53. Liu XY, Gurel V, Morris D, Murray DW, Zhitkovich A, Kane AB, Hurt RH (2007) Bioavailability of nickel in single-wall carbon nanotubes. Adv Mater 19:2790-2796

54. Zheng K, Setyawati MI, Leong DT, Xie J (2017) Antimicrobial gold nanoclusters. ACS Nano 11:6904-6910

Publisher's Note Springer Nature remains neutral with regard to jurisdictional claims in published maps and institutional affiliations. 